\title{
Fixation and redistribution of arsenic during early and late diagenesis in the organic matter-rich members of the Lockatong Formation, Newark basin, USA: implications for the quality of groundwater
}

\author{
LARBI RDDAD \\ Earth and Planetary Sciences Department, Kingsborough Community College, \\ City University of New York, Brooklyn, New York 11235, USA \\ $<$ Lrddad@gmail.com>
}

Date received: 01 June 2016 Date accepted: 17 April 2017

\begin{abstract}
The Byram and Walls Island members in the lower and upper sections, respectively, of the Lockatong Formation in the Newark basin near the border between Pennsylvania and New Jersey were chosen to assess (i) the role of euxinic/anoxic conditions in sequestering arsenic (As) and other trace elements and (ii) the redistribution of these elements during catagenetic transformations. These members are rich in organic matter and host pyrite which occurs as disseminations, small patches, and subparallel veins. The sulfur isotope values of pyrite samples range between -7.5 and $0.5 \%_{\mathrm{CDT}}$ (average $=-3.5 \%{ }_{\mathrm{CDT}}$ ). The negative $\delta^{34} \mathrm{~S}$ values are indicative of Bacterial Sulfate Reduction (BSR) under low temperature and euxinic/anoxic conditions. The total organic carbon (TOC) values in this member fluctuate between 0.5 and $2.1 \%$. These euxinic/anoxic conditions enhanced the incorporation of As and other trace elements in both organic matter and pyrite. The As concentrations range from 13 to $800 \mathrm{mg} / \mathrm{kg}$ and from 1.4 to $34 \mathrm{mg} / \mathrm{kg}$ in pyrite and black shale samples, respectively. Rock Eval analyses reveal that organic matter is over-mature which altered the correlation between TOC and As. The thermal cracking of organic matter resulted in the removal of these elements from organic matter and their subsequent incorporation in pyrite and bitumen. Organic matter- and pyrite-rich anoxic black shale layers and bitumen veins are potential sources of arsenic in groundwater in the Newark basin, with arsenic values that reach up to $215 \mu \mathrm{g} / \mathrm{L}$.
\end{abstract}

\section{RÉSUMÉ}

Les membres des îles Byram et Walls dans les sections inférieures et supérieures, respectivement, de la formation Lockatong dans le bassin Newark près de la frontière de la Pennsylvanie et du New Jersey ont été choisis pour évaluer: (i) le rôle des conditions euxiniques et anoxiques dans la séquestration de l’arsenic (As) et d’autres éléments traces; (ii) la redistribution de ces éléments durant les transformations catagénétiques. Ces membres sont riches en matière organique et contiennent de la pyrite qui se présente sous forme de disséminations, de petites plaques et de veines subparallèles. Les valeurs isotopiques du soufre des échantillons de pyrite varient de $-7,5$ à 0,5\%o ${ }_{\text {CDT }}$ (moyenne $=$ $\left.-3,5 \%{ }_{\mathrm{CDT}}\right)$. Les valeurs négatives $\delta^{34} \mathrm{~S}$ indiquent la présence de bactéries sulfato-réductrices qui ont réduit les sulfates à basse température et dans des conditions euxiniques et anoxiques. Les valeurs du carbone organique total (COT) dans ces membres varient entre 0,5 et 2,1\%. Ces conditions euxiniques et anoxiques ont renforcé l'incorporation de l'As et d'autres éléments en traces, tant dans la matière organique que dans la pyrite. Les concentrations d'As varient entre 13 et $800 \mathrm{mg} / \mathrm{kg}$ et de 1,4 à $34 \mathrm{mg} / \mathrm{kg}$ dans les échantillons de pyrite et de schiste noir, respectivement. Les analyses RockEval révèlent que lamatière organique présente une maturité avancée, altérant la corrélation entre le COT et l'As. Le craquage thermique de la matière organique a causé l'expulsion de ces éléments de la matière organique et leur incorporation subséquente dans la pyrite et le bitume. Les couches anoxique de schiste noire riche matière organique et en pyrite ainsi que les niveaux riche en veines de bitume sont des sources potentielles d'arsenic dans l'eau souterraine du bassin Newark, avec des valeurs d'arsenic atteignant jusqu’̀̀ $215 \mu \mathrm{g} / \mathrm{l}$.

[Traduit par la redaction] 


\section{INTRODUCTION}

Arsenic is a poisonous element that poses a health hazard in drinking water worldwide. It has an average crustal concentration of $1.8 \mathrm{mg} / \mathrm{kg}$ (Smedley and Kinniburgh 2002). Occurrences of geogenic arsenic have been found in the bedrock aquifers in the northeastern United States, leading many researchers to investigate different possible controls on the amount of As in these aquifers (Ayotte et al. 2003; Serfes et al. 2005; Lipfert et al. 2006; Peters and Burkert 2007; Peters 2008; Serfes et al. 2010; Ryan et al. 2013; Ryan et al. 2015; Blake and Peters 2015; O'Shea et al. 2015). These authors related the high As concentration either to the nature of the bedrock aquifers and/or to the geological processes affecting the bedrock (e.g., crustal recycling of As in the northern Appalachian mountain belt, Peters (2008); degree of metamorphism in western New England, Ryan et al. (2015)).

Newark basin groundwater has arsenic concentrations that exceed the standard limit $(<10 \mu \mathrm{g} / \mathrm{L})$ set by the USA Environmental Protection Agency (EPA) in public-water supplies. Fifteen percent of the 94 sampled New Jersey public-supply wells that tap the Lockatong and Passaic formations had As concentrations greater than $10 \mu \mathrm{g} / \mathrm{L}$ (Serfes et al. 2005). Two major sources of arsenic have been identified in the Newark basin: pyrite and hematite. Pyrite has been identified as the main source of As in black shale of the Lockatong Formation (Serfes et al. 2005; Serfes et al. 2010; Blake and Peters 2015; Rddad 2016). Hematite has been identified as another source of As in red mudstone of the Passaic Formation (Serfes et al. 2005). An increase in the amount of As has been also linked to the amount of organic matter in the Lockatong Formation aquifer (Serfes et al. 2005; Serfes et al. 2010; Blake and Peters 2015). Red mudstone, grey shale, and black shale of the Passaic and Lockatong formations in the Newark basin contain As concentrations of as much as $14.8,50$, and $240 \mathrm{mg} / \mathrm{kg}$, respectively (Serfes et al. 2005). Although the As content is higher in black shale layers compared to grey and red beds, no positive correlation occurs between total organic carbon (TOC) values and As concentration in the black shale (Rddad 2016). Besides the control by abundance of organic matter on the amount of As, the degree of organic matter $(\mathrm{OM})$ maturity, which can alter the OM-As relationship, is another control that should be taken into consideration. The purpose of this paper is to (i) investigate the conditions under which As and other TE were incorporated into both organic and inorganic phases, (ii) determine, if possible, the organic matter contents (TOC, pyrolyzable carbon (PC), and residual carbon (RC)) to which As is mainly linked, and (iii) the impact of the degree of OM maturity in the redistribution of As in different available organic (bitumen) and inorganic phases (pyrite). Ultimately, this study aims at verifying if the bitumen veins are potential sources of As in groundwater. It should be noted that the processes of mobilization of As from the bedrock to the groundwater are beyond the scope of this paper; readers are referred to Serfes et al. $(2005,2010)$ and Blake and Peters (2015) who investigated the processes that remobilize As from pyrite and released it into the groundwater.

The Walls Island and Byram members in the Nursery core and the Walls Island Member in the Titusville core were sampled because they represent the organic matterrich members of the Lockatong Formation. To complete this project, sulfur isotope analysis of pyrite, As and other trace element analyses of black shale, pyrite, and bitumen, and Rock-Eval analyses of black shale were performed.

\section{GEOLOGY}

\section{Geological setting}

The early Mesozoic Newark basin is one of the most studied Newark supergroup rift basins in the northeastern United States (Fig. 1). The Newark basin is an elongate half-graben that is $190 \mathrm{~km}$ long and up to $50 \mathrm{~km}$ across (Olsen 1986). The Precambrian and early Paleozoic rocks representing the southwestern Appalachian part of the New England upland border the Newark basin to the northeast. To the southeast, the basin is bordered by the Paleozoic and Precambrian Appalachian highlands of the Blue Ridge and Piedmont provinces (Olsen 1980). The Appalachian

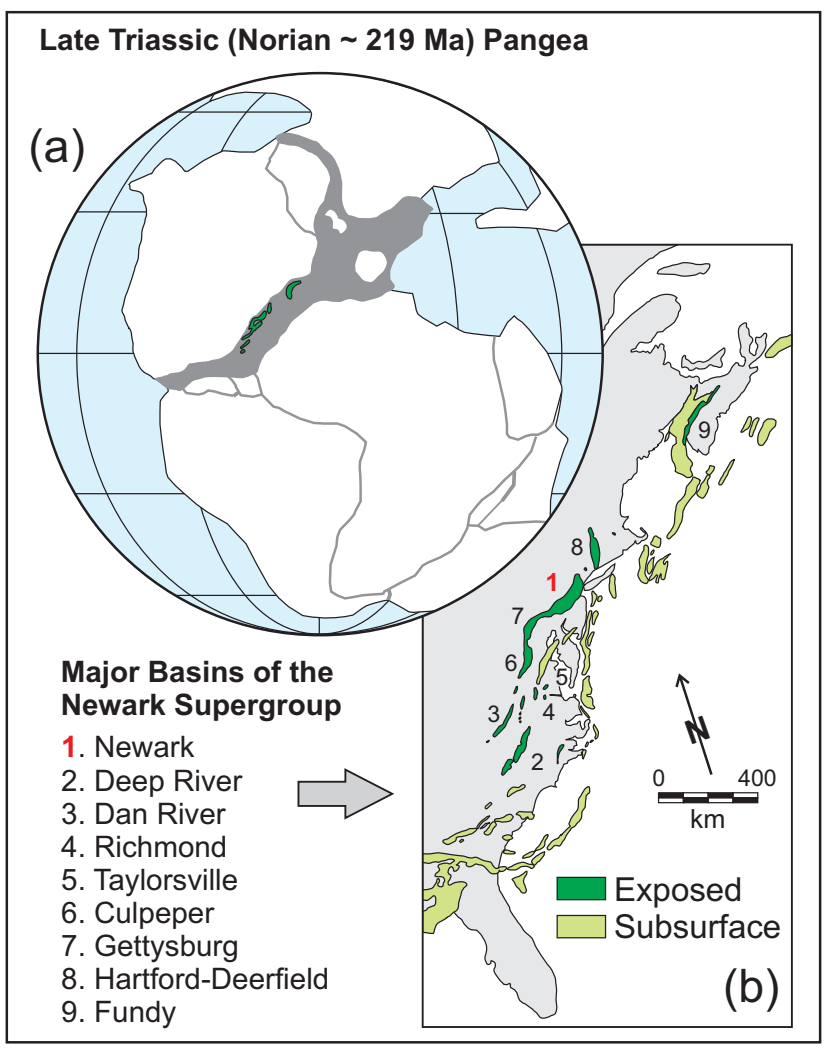

Figure 1. (a) Reconstruction of Pangea for the middle Norian showing the zone of early Mesozoic rifting (shaded) and the preserved basins of the Newark Supergroup (green). (b) Early Mesozoic rift basins of eastern North America (after Olsen et al. 1996). 
highlands are the result of collisions between the North American continent and various Gondwanan fragments, including Africa, during the Paleozoic, leading to the formation of the supercontinent Pangea (e.g., Nance and Linneman 2008).

The Newark basin underwent rifting during the breakup of Pangea and the opening of the Atlantic Ocean (Manspeizer 1988). During this continental rifting, the Triassic extensional tectonic activity led to the reactivation of Paleozoic NE-SW-trending major faults, and subsequently the formation of a half-graben (Ratcliffe et al. 1986; Schlische et al. 2003). The resulting basin was filled by 6 to $8 \mathrm{~km}$ of non-marine, lacustrine sediments intercalated with a few basaltic flows (Olsen et al. 1996). The sediments were derived from weathering and erosion of the surrounding Precambrian and Paleozoic highlands (Schlische and Olsen 1990), which consist mainly of granitic gneiss, schist, and minor mafic rocks (Serfes et al. 2010). The main sources of arsenic were the mafic and sulfide minerals (Van Houten 1964; El Tabakh and Schreiber 1998; Serfes et al. 2010). Overlying the Precambrian-Paleozoic basement are Triassic-Jurassic fluvio-lacustrine formations (Olsen 1986), which are listed and briefly described below from oldest to youngest:
(1) Stockton Formation (1800 m) - alluvial/fluvial arkosic and sandstone facies.

(2) Lockatong Formation (1000 - $2000 \mathrm{~m})$ - mainly cyclic organic matter-rich black shale and grey to red mudstone, siltstone, and sandstone facies with intercalations of argillaceous carbonate (e.g., Van Houten 1964; Olsen 1986).

(3) Passaic Formation (2800 m) - mainly red mudstone and sandstone containing evaporites with minor lacustrine black shale beds.

(4) Jurassic rocks $(300-400 \mathrm{~m})$ - clastic sedimentary rocks intercalated with basaltic flows and intruded by finegrained gabbro.

\section{Lithostratigraphic description of the sampled core}

The samples for this study were collected from the Walls Islands Member and the Byram Member which, respectively, represent the upper and lower organic matterrich sections of the Lockatong Formation (Fig. 2). Two cores were chosen for this project: the Titusville and Nursery cores (Fig. 2). These cores represent part of 6770 $\mathrm{m}$ of core obtained from the Newark Basin Continental Drilling Project (NBCDP).

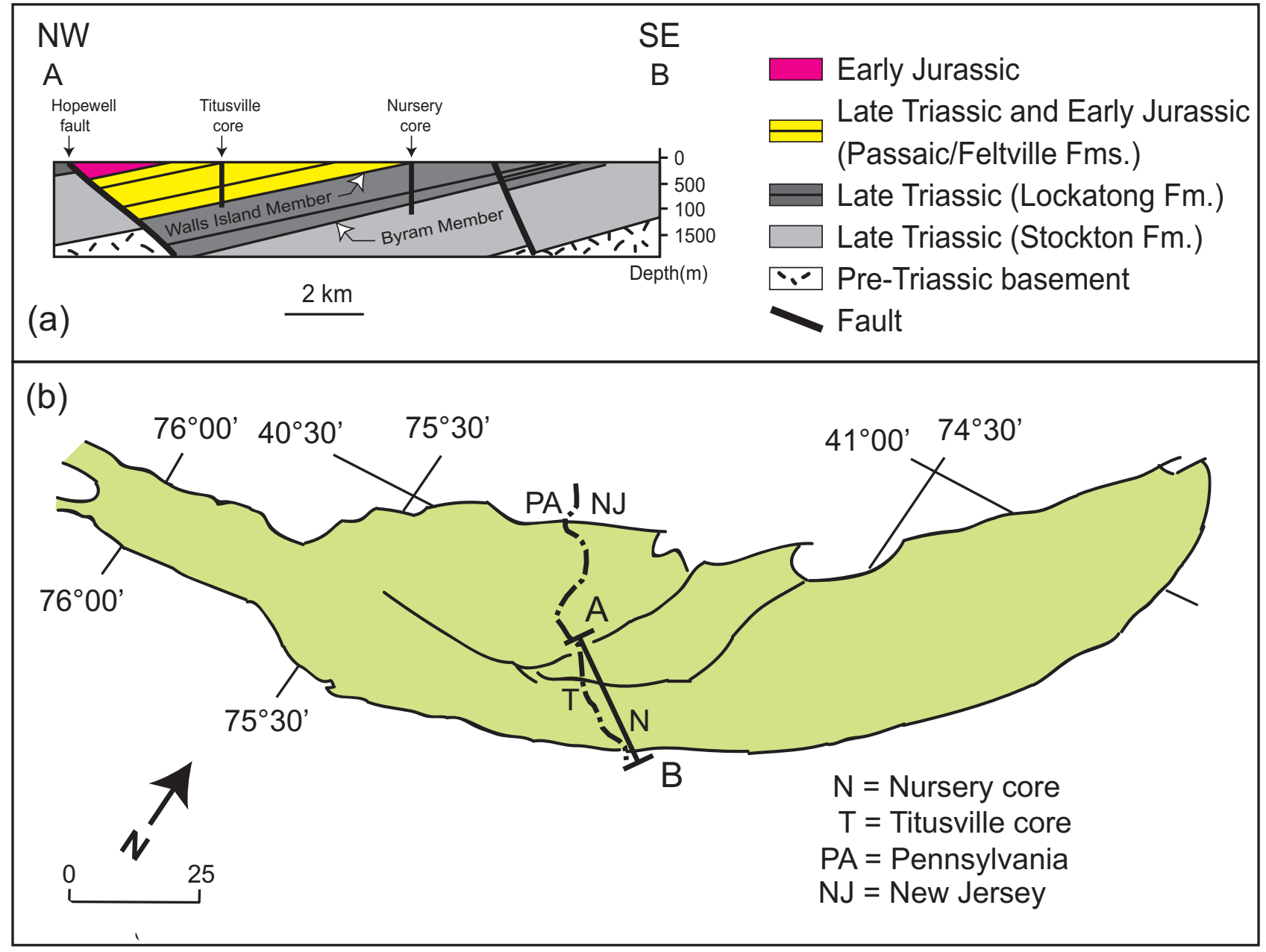

Figure 2. Geologic cross section A-B in the Newark basin showing the Titusville and Nursery cores (a) and location of A-B cross section in the Newark basin (b) (after Olsen et al. 1996). 
The Walls Island and Byram members, described in Figures 3 and 4, consist mainly of black shale intercalated with grey to light grey shale and pinkish-grey shale. This succession reflects the development of small-scale anoxic events (black shale) separated by oxic to suboxic events (light grey to pinkish-grey shale). The black shale, typically rich in organic matter, contain pyrite as disseminated, euhedral to subhedral, millimetre- to centimetre-size crystals, and as small horizontal veins. The light grey to pinkish-grey shales commonly host numerous bitumenfilled fractures typically associated with calcite.

\section{SAMPLING AND METHODS}

Seven samples of black shale and six samples of pyrite were collected from the Walls Island and Byram members of the Lockatong Formation in the Nursery and Titusville cores of the Newark basin. Six shale samples were collected at different depths from dark layers and one from a light grey layer. Pyrite samples were exclusively collected from dark layers. Two bitumen samples were collected from the bitumen-rich veins hosted in the grey shale in the Nursery and Titusville cores.

Pyrite samples were carefully crushed and handpicked under a binocular microscope. Isotopic analyses were carried out on five samples at the spectrometry facility at the Department of Engineering, University of Nevada. Sulfur isotope analyses were performed using a Eurovector elemental analyzer connected to a Micromass isoprime stable isotope ratio mass spectrometer, after the methods of Giesemann et al. (1994) and Grassineau et al. (2001). Sulfur isotopic compositions in pyrite samples are expressed as $\delta^{34} \mathrm{~S}$ values relative to the Vienna Canyon Diablo Troilite (VCDT) standard. Reproducibility was $\pm 0.2 \%$ o for sulfur.

Analyses of arsenic and other trace elements in black shale and bitumen samples were performed at Activation Laboratories Ltd (Actlabs) using INAA (Instrumental Neutron Activation Analysis). INAA is an analytical technique dependent on measuring gamma radiation induced in the sample by irradiation with neutrons. The primary source of neutrons for irradiation is usually a nuclear reactor. Each activated element emits a "fingerprint" of gamma radiation which can be measured and quantified. Routine multi-element analyses by INAA are performed on practically any material from the smallest sample which can be weighed accurately to very large samples. A $30 \mathrm{~g}$ aliquot of sample is encapsulated in a polyethylene vial and irradiated with flux wires, standards, and blanks at a thermal neutron flux of $7 \times 10^{12} \mathrm{ncm}^{-2} \mathrm{~s}^{-1}$. The samples are measured the next day for the induced Au-198 photopeak at $411.8 \mathrm{KeV}$. Samples are compared to a calibration developed from multiple international reference materials. After a 7-day period to allow $\mathrm{Na}-24$ to decay the samples are counted on a high purity Ge detector with resolution of better than $1.7 \mathrm{KeV}$ for the $1332 \mathrm{KeV}$ Co-60 photopeak. Using the flux wires, the decay-corrected activities are compared to a calibration developed from

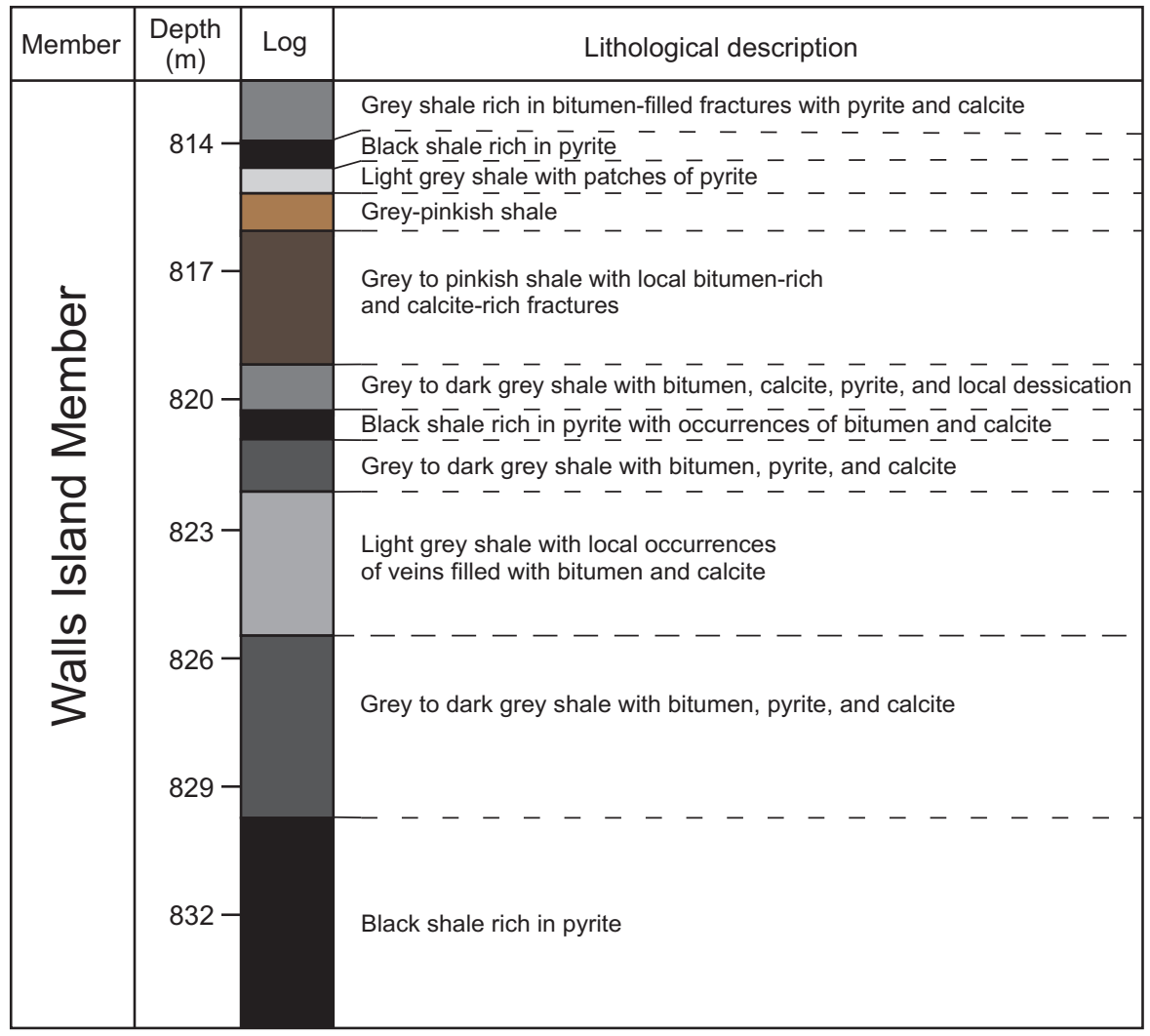

Figure 3. Log of the Walls Island Member of the Lockatong Formation in the Titusville core, Newark basin. 


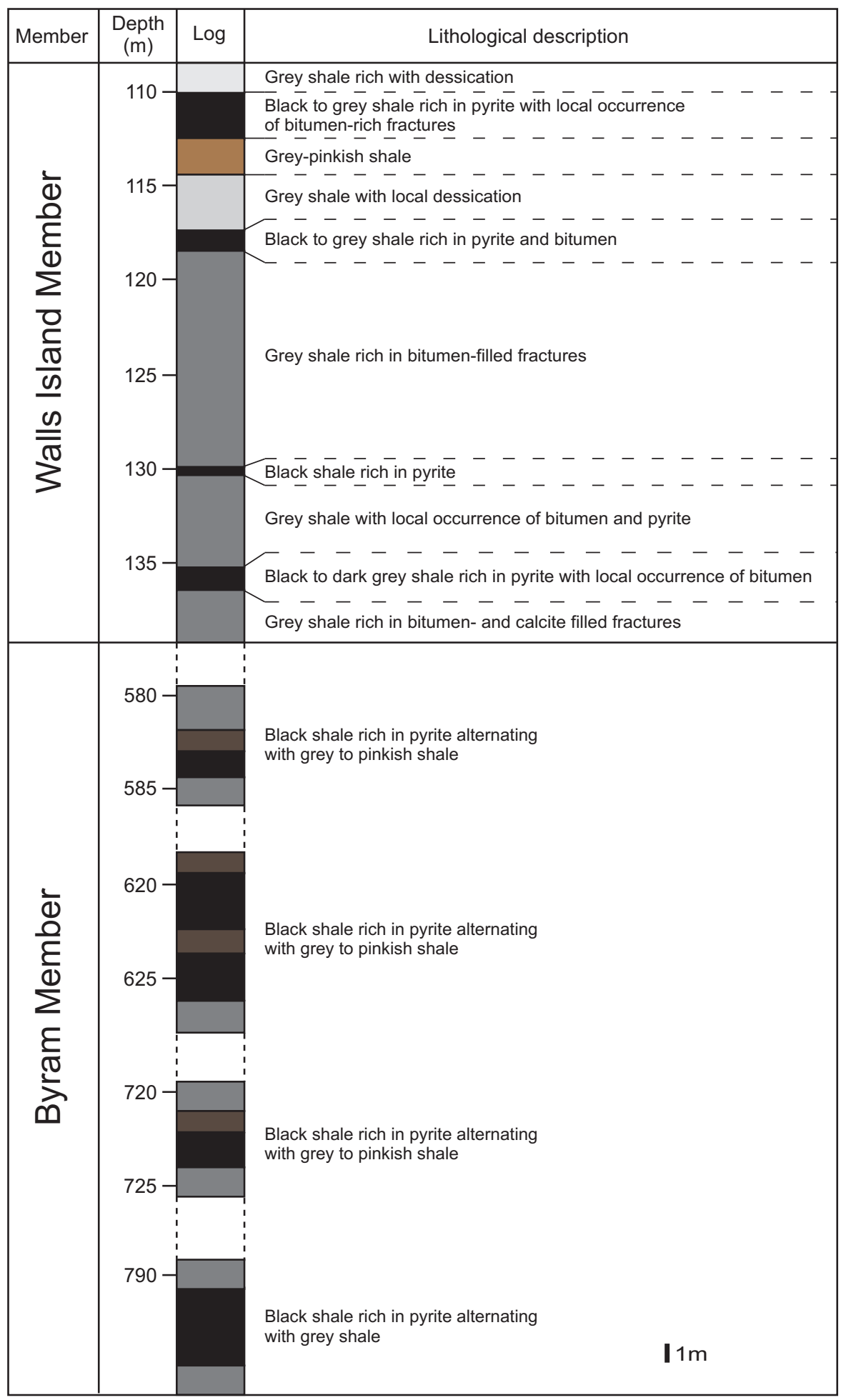

Figure 4. Log of the Walls Island Member and the Byram Member of the Lockatong Formation in the Nursery core, Newark basin.

multiple certified international reference materials. The standard provides a check on accuracy and is not used for calibration purposes. From $10-30 \%$ of the samples are rechecked by re-measurement. For values exceeding the upper limits, assays are recommended. One standard is run for every 11 samples. One blank is analyzed per work order.
Duplicates are analyzed when samples are provided.

The analysis of bitumen for As and other TE using laser ablation-inductively coupled plasma-mass spectrometry (LA-ICP-MS) was attempted. The bitumen samples did not ablate very well and intensities on almost all masses were very low and signals were unstable. Moreover, carbon- 
derived standards were not used. Therefore, the results from the LA-ICP-MS of the bitumen are not considered here.

The total organic carbon (TOC) analyses of the black shale samples were also performed at Actlabs. The C-Organic is calculated according to the following equation: $\mathrm{C}$-Organic $=$ Total C $-\mathrm{C}_{\mathrm{CO} 2}-\mathrm{C}_{\text {Graphitic }}$. Carbon analysis is performed by the absorption of IR energy which can be attributed only to carbon dioxide $\left(\mathrm{CO}_{2}\right)$ which absorbs IR energy at a precise wavelength within the IR spectrum. The concentration of $\mathrm{CO}_{2}$ is detected as a reduction in the level of energy at the detector. It can be measured in either an inert atmosphere or an oxygen atmosphere (binding carbon species with the oxygen to form $\mathrm{CO}$ (converted to $\mathrm{CO}_{2}$ prior to detection) and $\mathrm{CO}_{2}$, the majority being $\mathrm{CO}_{2}$, and is measured as carbon dioxide in the IR cell as gases flow through the IR cells. Energy from the IR source is absorbed as the gas passes through the cell, preventing it from reaching the IR detector. All other IR energy is prevented from reaching the IR detector by a narrow bandpass filter. Because of the filter, the absorption of IR energy can be attributed only to carbon dioxide $\left(\mathrm{CO}_{2}\right)$. The concentration of $\mathrm{CO}_{2}$ is detected as a reduction in the level of energy at the detector.

Programmed pyrolysis was performed on 12 black shale samples using Rock-Eval 6 in the commercial laboratories of Weatherfordlab (www.weatherfordlabs.com). The RockEval technique is used to identify the type of organic matter, assess the source rock potential, and the thermal maturity of organic matter (Tissot and Welte 1978). Approximately $100 \mathrm{mg}$ of sample was powdered and placed in an inert atmosphere (helium) and combusted at a programmable temperature from $250^{\circ} \mathrm{C}$ to $550^{\circ} \mathrm{C}$, and a speed of $25^{\circ} \mathrm{C} /$ min. A detailed description of the procedure is given by Espitalié et al. (1985). Pyrolyzed hydrocarbons and carbon dioxide are measured as a function of temperature, where $S_{1}$ represents free hydrocarbons in the kerogen and $S_{2}$ represents pyrolyzable hydrocarbons generated by pyrolysis related to the petroleum-generating potential of the sediment. $\mathrm{S}_{2}$ is normalized to TOC to calculate the hydrogen index $(\mathrm{HI})$, which is proportional to the kerogen elemental $\mathrm{H} / \mathrm{C}$ ratio. In a similar way, the pyrolyzable $\mathrm{CO}_{2}$ is measured and normalized to TOC to determine the oxygen index (OI), which is in some cases proportional to the kerogen elemental $\mathrm{O} / \mathrm{C}$ ratio. $\mathrm{T}_{\max }$ is the temperature at which the $\mathrm{S}_{2}$ peak reaches its maximum evolution.

Trace elements were analyzed in six pyrite samples using laser ablation-inductively coupled plasma-mass spectrometry (LA-ICP-MS) at the U.S Geological Survey in Denver. Images of grains of interest were used to guide LA-ICP-MS analyses. A Photon Machines Analyte G2 LA system (193 nm, 4 ns excimer) was coupled to a PerkinElmer DRC-e ICP-MS. Spot analyses were used for individual analyses of known location. Typical operating conditions for these analyses are listed in Table 1. Ablation was carried out using a 50 -micrometre spot size at $5 \mathrm{~J} / \mathrm{cm}^{2}$. Single spot analyses were ablated using 5 pulses/sec $(5 \mathrm{~Hz})$. Ablated
Table 1. Laser System used for LA-ICP-

MS analyses of pyrite.

\begin{tabular}{lc}
\hline Wavelength & $193 \mathrm{~nm}$ \\
Spot Size & $50 \mu \mathrm{m}$ \\
Pulse Frequency & $5 \mathrm{~Hz}$ (spots) \\
Energy Density & $\sim 5 \mathrm{~J} / \mathrm{cm}^{2}$ \\
\hline
\end{tabular}

material was transported via a He carrier gas to a modified glass mixing bulb where the $\mathrm{He}+$ sample was mixed coaxially with Ar prior to the ICP torch. Concentration and detection limit calculations were conducted using the protocol of Longerich et al. (1996). Signals were calibrated using USGS MASS-1 sulfide reference material (Wilson et al. 2002). The reference material (MASS-1) was analyzed 5-10 times at the beginning of the analytical session and monitored throughout the session for drift. Iron $\left({ }^{57} \mathrm{Fe}\right)$ was used as the internal standard for concentration calculations. Signals were screened visually for heterogeneities such as micro-inclusions or zoning.

\section{RESULTS AND DISCUSSION}

The sulfur isotopes in pyrite, arsenic concentrations in pyrite, black shale, and bitumen samples, total organic carbon (TOC), and Rock-Eval data are reported in Tables 2-5.

\section{Sulfur isotopes}

The $\delta^{34} \mathrm{~S}$ values for pyrite range between -7.5 and +0.5 $\%_{\mathrm{CDT}}\left(\right.$ average $\left.=-3.5 \% 0_{\mathrm{CDT}}, \mathrm{n}=5\right)$ (Table 2). These values are lower than those of Triassic seawater $\left(\delta^{34} S=+11\right.$ to 20 $\%$ ) and Jurassic seawater $\left(\delta^{34} \mathrm{~S}=+14\right.$ to $18 \%$ ) (Fig. 5) (Claypool et al. 1980). This indicates that the Newark basin was isolated from the open ocean. On the basis of Sr isotopic composition of sulphates in the Passaic Formation, El Tabakh et al. (1997) reached the same conclusion. TriassicJurassic seawaters are, therefore, excluded as a source of sulfur. This leads to the conclusion that the source of sulfur

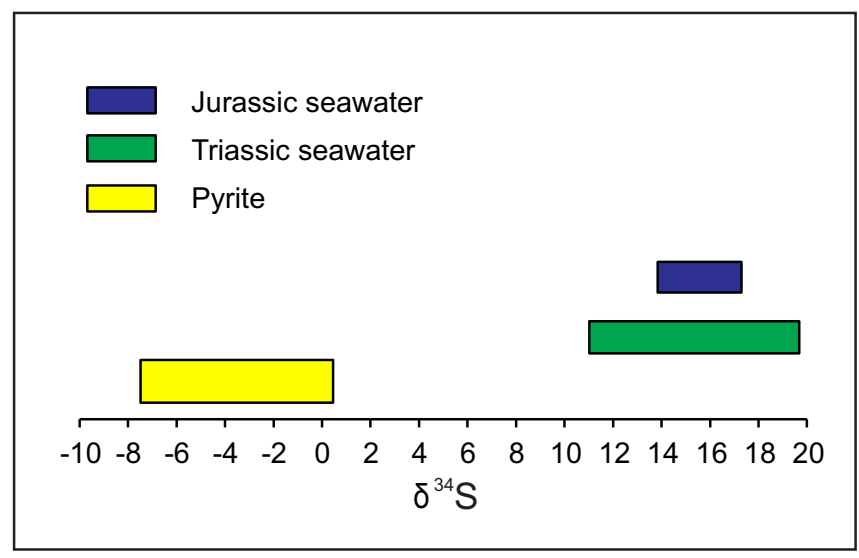

Figure 5. The sulfur isotopic composition of the analyzed pyrite compared to that of Triassic and Jurassic seawaters (Claypool et al. 1980). 
Table 2. Sulfur isotopic composition of pyrite hosted in the Lockatong Formation in the Nursery and Titusville cores. (Numbers in sample reference indicate depth of the samples in feet).

\begin{tabular}{lccc}
\hline \multicolumn{1}{c}{ Sample } & Depth $(\mathrm{m})$ & Mineral & $\delta^{34} \mathrm{~S}_{\mathrm{VCDT}}(\%)$ \\
\hline N1916.15py & 584.04 & Pyrite & 0.5 \\
N2035.8py & 620.27 & Pyrite & -7 \\
T2693py & 820.83 & Pyrite & 0.5 \\
T2727.6py & 831.37 & Pyrite & -7 \\
T2729.2py & 831.86 & Pyrite & -7.5 \\
\hline
\end{tabular}

Table 3. Concentrations $(\mathrm{mg} / \mathrm{kg})$ of trace elements in pyrite hosted in the Nursery and Titusville cores of the Lockatong Formation.

\begin{tabular}{|c|c|c|c|c|c|c|c|c|c|}
\hline \multicolumn{2}{|c|}{ Sample } & $\mathrm{N} 362.4 \mathrm{Py}$ & N383.7Py & $\mathrm{N} 430.4 \mathrm{Py}$ & T2693Py & T2727.6Py & T2729.2aPy & T2729.2bPy & $\mathrm{T} 2729.2 \mathrm{cPy}$ \\
\hline \multicolumn{2}{|c|}{ Depth (m) } & 111 & 117 & 131 & 821 & 831 & 832 & 832 & 832 \\
\hline \multicolumn{2}{|c|}{ \# Spots } & 6 & 4 & 5 & 5 & 5 & 3 & 3 & 3 \\
\hline \multirow{3}{*}{$\begin{array}{c}\text { As } \\
(2.43)\end{array}$} & $\min$ & 13.1 & 41.4 & 335 & 22.2 & 44 & 53.5 & 216 & 121.9 \\
\hline & $\max$ & 49.2 & 176.1 & 799.9 & 263.3 & 211.3 & 221.9 & 424.2 & 233.8 \\
\hline & mean & 27.2 & 105.8 & 533.7 & 134.2 & 114.8 & 128 & 317.8 & 180.6 \\
\hline \multirow{3}{*}{$\begin{array}{c}\mathrm{Mn} \\
(3.76)\end{array}$} & $\min$ & 16.7 & 30.4 & 34.1 & 19 & 20.6 & 19.8 & 23.1 & 24.2 \\
\hline & $\max$ & 32.1 & 39.7 & 7052.8 & 27.3 & 197.5 & 31.3 & 28.1 & 105.6 \\
\hline & mean & 23 & 34.1 & 1465.4 & 23.9 & 62.3 & 24.2 & 25.9 & 51.7 \\
\hline \multirow{3}{*}{$\begin{array}{c}\text { Co } \\
(2.24)\end{array}$} & $\min$ & 2.5 & 3.4 & 22.9 & 8.2 & 29.5 & 2.5 & 2.6 & 32 \\
\hline & $\max$ & 9.7 & 7.7 & 53.2 & 13.1 & 95.4 & 4.3 & 2.6 & 32 \\
\hline & mean & 4.5 & 5.3 & 53.2 & 10.3 & 51.2 & 3.6 & 2.6 & 32 \\
\hline \multirow{3}{*}{$\begin{array}{c}\mathrm{Ni} \\
(8.94)\end{array}$} & $\min$ & 9.5 & - & 33 & 10.7 & 46.8 & 36.9 & 33.9 & 10.9 \\
\hline & $\max$ & 20.9 & - & 142.7 & 11.6 & 256.7 & 96.2 & 40 & 58.6 \\
\hline & mean & 13.2 & - & 98.9 & 11.2 & 113.8 & 57 & 37.5 & 39.2 \\
\hline \multirow{3}{*}{$\begin{array}{c}\text { Mo } \\
(2.51)\end{array}$} & $\min$ & 17.1 & 17.7 & 38 & 31.6 & 15.7 & 30.4 & 36.6 & 46.5 \\
\hline & $\max$ & 175.7 & 35 & 71.2 & 278.4 & 55.3 & 75.9 & 46.1 & 54.9 \\
\hline & mean & 58.4 & 25.7 & 56.9 & 128 & 25.5 & 53.9 & 42.1 & 51.1 \\
\hline \multirow{3}{*}{$\begin{array}{c}\mathrm{Sb} \\
(0.625)\end{array}$} & $\min$ & 3.1 & 13.3 & 17.1 & 4.2 & 4.5 & 13.8 & 30.3 & 36.4 \\
\hline & $\max$ & 8.7 & 24.6 & 62.6 & 115.1 & 23.2 & 42.1 & 44.3 & 63.6 \\
\hline & mean & 6.6 & 18.1 & 47.7 & 51.4 & 9.8 & 31.1 & 36.6 & 48.8 \\
\hline \multirow{3}{*}{$\begin{array}{c}\mathrm{Tl} \\
(0.16)\end{array}$} & $\min$ & 0.2 & 0.2 & 3.8 & 0.3 & 0.2 & 0.8 & 2.5 & 0.5 \\
\hline & $\max$ & 0.9 & 1.2 & 10.6 & 0.4 & 1.8 & 3.1 & 4.8 & 1.9 \\
\hline & mean & 0.6 & 0.5 & 7.8 & 0.3 & 0.8 & 1.6 & 3.6 & 1.3 \\
\hline \multirow{3}{*}{$\begin{array}{c}\mathrm{Pb} \\
(0.589)\end{array}$} & $\min$ & 3.8 & 10.1 & 116.5 & 12.3 & 40.3 & 18.2 & 11.7 & 13.7 \\
\hline & $\max$ & 45.7 & 49.6 & 581 & 233.3 & 277.1 & 58.7 & 26.6 & 154 \\
\hline & mean & 22.3 & 23.9 & 363.1 & 102.9 & 125.1 & 34.8 & 20.3 & 61.3 \\
\hline
\end{tabular}

Notes: ${ }^{\star}$ Detection limit in $\mathrm{mg} / \mathrm{kg}$ for the analyzed trace elements and shown in brackets under element; ${ }^{\star *}$ Numbers in sample reference indicate depth of the sample in feet; $\mathrm{N}=$ Nursery and $\mathrm{T}=$ Titusville. 
Table 4. Rock Eval data for the pyrolyzed black shale samples from the Nursery and Titusville cores, Newark basin. Detection limit for TOC is $0.5 \%$.

\begin{tabular}{|c|c|c|c|c|c|c|c|}
\hline \multirow{2}{*}{$\begin{array}{c}\text { Core } \\
\text { Sample }\end{array}$} & \multicolumn{4}{|c|}{ Nursery } & \multicolumn{3}{|c|}{ Titusville } \\
\hline & N362.4 & N381.3 & N383.7 & N429 & T2671 & T2693 & T2727.6 \\
\hline Depth (m) & 111 & 116 & 117 & 131 & 814 & 821 & 831 \\
\hline TOC \% & 2.72 & 0.6 & 1.71 & 0.79 & 1.9 & 0.8 & 1.2 \\
\hline $\mathrm{S}_{1} \mathrm{mg} / \mathrm{g}$ & 0.07 & 0.05 & 0.08 & 0.03 & 0.11 & 0.04 & 0.06 \\
\hline $\mathrm{S}_{2} \mathrm{mg} / \mathrm{g}$ & 0.39 & 0.19 & 0.31 & 0.18 & 0.15 & 0.13 & 0.16 \\
\hline $\mathrm{S}_{3} \mathrm{mg} / \mathrm{g}$ & 0.34 & 0.20 & 0.25 & 0.22 & 0.26 & 0.25 & 0.18 \\
\hline $\operatorname{Tmax}{ }^{\circ} \mathrm{C}$ & 595 & 510 & 542 & 522 & 304 & 332 & 608 \\
\hline $\mathrm{R}_{0}^{*}{ }^{\circ} \mathrm{C}$ & - & - & 1.94 & - & - & - & 2.39 \\
\hline $\operatorname{Tmax}^{*}{ }^{\circ} \mathrm{C}$ & - & - & 506 & - & - & - & 531 \\
\hline $\mathrm{HI}$ & 14.3 & 31.8 & 18.2 & 22.7 & 8.0 & 16.1 & 13.9 \\
\hline OI & 12.5 & 33.4 & 14.7 & 27.7 & 13.9 & 31.0 & 15.7 \\
\hline $\mathrm{S}_{2} / \mathrm{S}_{3}$ & 1.15 & 0.95 & 1.24 & 0.82 & 0.60 & 0.50 & 0.90 \\
\hline$\left(\mathrm{S}_{1} / \mathrm{TOC}\right) \times 100$ & 2.57 & 8.36 & 4.69 & 3.78 & 5.90 & 5.00 & 5.20 \\
\hline PI & 0.15 & 0.21 & 0.21 & 0.14 & 0.40 & 0.20 & 0.30 \\
\hline PC wt \% & 0.04 & 0.02 & 0.03 & 0.02 & 0.02 & 0.01 & 0.02 \\
\hline RC wt\% & 2.68 & 0.58 & 1.67 & 0.78 & 1.84 & 0.79 & 1.13 \\
\hline GP wt\% & 0.46 & 0.24 & 0.39 & 0.21 & 0.26 & 0.17 & 0.22 \\
\hline
\end{tabular}

Notes: TOC: Total Organic Carbon, wt \%; $\mathrm{S}_{1}$ : Volatile/free hydrocarbon (HC) content, mg HC/g rock; $\mathrm{S}_{2}$ : Remaining $\mathrm{HC}$ generative potential, $\mathrm{mg} \mathrm{HC} / \mathrm{g}$ rock; $\mathrm{S}_{3}$ : Carbon dioxide content, $\mathrm{mg} \mathrm{CO}_{2} /$ g rock; $\mathrm{T}_{\max }{ }^{*}$ : Temperature of peak $\mathrm{S}_{2}$ maximum, ${ }^{\circ} \mathrm{C} ; \mathrm{R}_{0}{ }^{*}$ : Vitrinite reflectance from Malinconico (2010); $\mathrm{T}_{\max }$ Calculated Tmax based on $\mathrm{R}_{0}$ using $\mathrm{R}_{0}+7.16$ )/0.018 equation (after Peters et al $\square$ 2005), ${ }^{\circ} \mathrm{C}$; HI: Hydrogen Index $=\left(S_{2} \times 100\right) /$ TOC, mg HC/g TOC; OI: Oxygen Index $=\left(S_{3} \times 100\right) /$ TOC, mg CO $2 / g$ TOC; PI: Production Index $=\mathrm{S}_{1} /\left(\mathrm{S}_{1}+\mathrm{S}_{2}\right)$; PC: Pyrolysable Organic Carbon $=$ $\left(\left(S_{1}+S_{2}\right) / 10\right)$ x 0.83, wt \%; RC: Residual Organic Carbon = TOC - PC, wt\%; GP: Genetic Potential $=\mathrm{S}_{1}+\mathrm{S}_{2}$.

Table 5. Concentration of trace elements ( $\mathrm{mg} / \mathrm{kg}$ ) and major element Fe (in \%) in black shale and bitumen of the Nursery and Titusville cores.

\begin{tabular}{|c|c|c|c|c|c|c|c|c|c|}
\hline \multirow{2}{*}{$\frac{\text { Core }}{\text { Sample }^{\star \star}}$} & \multicolumn{5}{|c|}{ Nursery } & \multicolumn{4}{|c|}{ Titusville } \\
\hline & N362.4 & N381.3 & N383.7 & N429 & N433 Bit. & $\mathrm{T} 2671$ & T2693 & T2727.6 & T2701.5 Bit. \\
\hline Depth (m) & 111 & 116 & 117 & 131 & 132 & 814 & 821 & 831 & 823 \\
\hline As (0.5) & 15.4 & 1.4 & 33.6 & 24.6 & 103 & 17.1 & 22.9 & 20.9 & 70.8 \\
\hline Co (1.0) & 16 & 36 & 20 & 26 & 10 & 19 & 34 & 26 & 70 \\
\hline $\operatorname{Cr}(5.0)$ & 67 & 90 & 63 & 82 & 26 & 73 & 84 & 79 & 66 \\
\hline $\mathrm{Fe}(0.01)$ & 3.75 & 5.49 & 4.66 & 6.18 & 1.9 & 4.14 & 5.42 & 4.33 & 5.12 \\
\hline $\mathrm{Ni}(20)$ & - & - & - & - & 43.4 & - & - & - & 34.1 \\
\hline Mo (1.0) & 25 & - & 94 & - & - & 230 & 34 & 5 & - \\
\hline Th $(0.2)$ & 6.1 & 15.9 & 7.9 & 5.4 & 41 & 10.6 & 6.7 & 8.6 & 24.5 \\
\hline $\mathrm{U}(0.5)$ & 12.1 & 14.1 & 10.4 & 8.6 & 34 & 14.6 & 10.4 & 10.9 & 22 \\
\hline
\end{tabular}

Notes: ${ }^{\star}$ Detection limit for Fe is given in $\%$ and detection limit for trace elements is given in $\mathrm{mg} / \mathrm{kg}$ in brackets; - Below detection limit; ${ }^{*}$ Numbers in sample reference indicate depth of the sample in feet; $\mathrm{N}=$ Nursery, $\mathrm{T}=$ Titusville, Bit. $=$ Bitumen. 
may be the dissolved sulfates carried by streams to the lake.

Two pathways are possible for reducing sulfates via bacterial sulfate reduction (BSR): open and closed systems, depending on the availability of dissolved sulfates (Machel 2001; Gomes and Hurtgen 2013, 2015).

Under open conditions (i.e., oxidizing to slightly reducing) where dissolved sulfate is continuously replenished, the dissolved $\mathrm{SO}_{4}^{-2}$ will be reduced to light ${ }^{32} \mathrm{~S}$ which will be incorporated in pyrite. Conversely, under closed conditions (i.e., euxinic), where dissolved $\mathrm{SO}_{4}^{2}$ is limited, all available dissolved sulfates will be reduced to sulfur. As the sulfate reduction continues, the light isotope is incorporated in pyrite while the remaining/residual sulfate reservoir becomes enriched in heavy ${ }^{34} \mathrm{~S}$ (e.g., Jørgensen 1979; Gautier 1986; Lyons 1997). Therefore, the $\delta^{34} \mathrm{~S}$ in pyrite becomes heavier with time.

The low negative $\delta^{34} S$ values recorded in pyrite samples are indicative of BSR under slightly reducing conditions. It is also possible that BSR took place under closed conditions where most of the pyrite formation occurred before enrichment of ${ }^{34} \mathrm{~S}$ in the remaining sulfate reservoir (Sælen et al. 1993). Pyrite is known to form under the reducing conditions found in black shales (Berner 1984). Low Co/ $\mathrm{Ni}$ ratio $(<1)$ and the high concentration of $\mathrm{Ni}$ in the pyrite samples suggest syngenetic/diagenetic origin of these pyrite grains (Loftus-Hills and Solomon 1967; Bajwah et al. 1987) in an organic-rich environment (Dill and Kemper 1990; Guy et al. 2010). The Th/U ratios in black shales can be used to estimate the paleo-redox conditions because of the contrasting behavior of Th and U (Tribovillard et al. 2005; Pattan and Pearce 2009). Lower Th/U values indicate anoxic conditions whereas higher values point to dysoxic and oxic conditions (Jones and Manning 1994; Pattan and Pearce 2009). The very low $T h / U$ values for the analyzed black shale samples $(\mathrm{Th} / \mathrm{U}=0.50-1.13)$ indicate strong anoxic conditions in which organic matter was accumulated and the analyzed pyrite grains were formed. This conclusion is supported by the inverse correlation between $\mathrm{Th} / \mathrm{U}$ ratio and TOC values (Fig. 6) and the abundance of pyrite in organic matter-rich black shales in the sampled members.

In conclusion, the reduced sulfur is derived from the BSR of dissolved sulfate in euxinic/ anoxic conditions. This sulfur combined with the reactive available iron to form diagenetic pyrite. The latter are more abundant in the OMrich black shales.

\section{Arsenic in pyrite}

Arsenic values in the pyrite samples range from 13 to 800 $\mathrm{mg} / \mathrm{kg}(\mathrm{mean}=217 \mathrm{mg} / \mathrm{kg}$ ) and from 22 to $425 \mathrm{mg} / \mathrm{kg}$ (mean $=165 \mathrm{mg} / \mathrm{kg})$, respectively, in the Nursery and Titusville cores (Table 3). The concentration of arsenic in pyrite of the Newark basin can reach a maximum range of 3,000 to $40,000 \mathrm{mg} / \mathrm{kg}$ (Serfes et al. 2005). Pyrite is considered as a potential sink for arsenic in the Newark basin (Serfes et al. 2005) and also for other TE, particularly $\mathrm{Pb}, \mathrm{Ni}, \mathrm{Mo}$, and Co. The other trace element concentrations in pyrite show

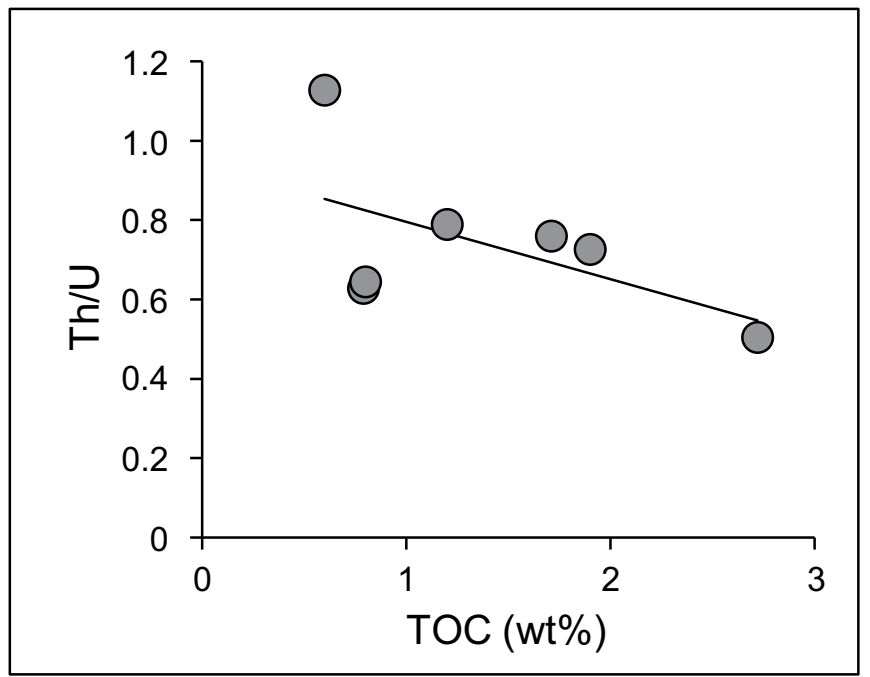

Figure 6. Plot TOC versus $\mathrm{Th} / \mathrm{U}$ ratio in the black shale samples from the Titusville and the Nursery cores.

the following trend $\mathrm{As}>\mathrm{Pb}>\mathrm{Ni}>\mathrm{Mo}>\mathrm{Mn}>\mathrm{Co}>\mathrm{Sb}>\mathrm{Tl}$ for the Nursery core samples and $\mathrm{As}>\mathrm{Pb}>\mathrm{Mo}>\mathrm{Ni}>\mathrm{Mn}>\mathrm{Sb}>\mathrm{Co}>\mathrm{Tl}$ for the Titusville core samples. The incorporation of As in pyrite may have facilitated that of other TE due mainly to the significant distortion/defects of the pyrite structure (Deditius et al. 2008). At the sample scale, the core of centimetre-sized pyrite crystals is enriched relative to the rims (Fig. 7). This enrichment is explained by the removal of arsenic by early pyrite crystals, which caused depletion in the remaining residual fluid. Serfes et al. (2005) reached the same conclusion.

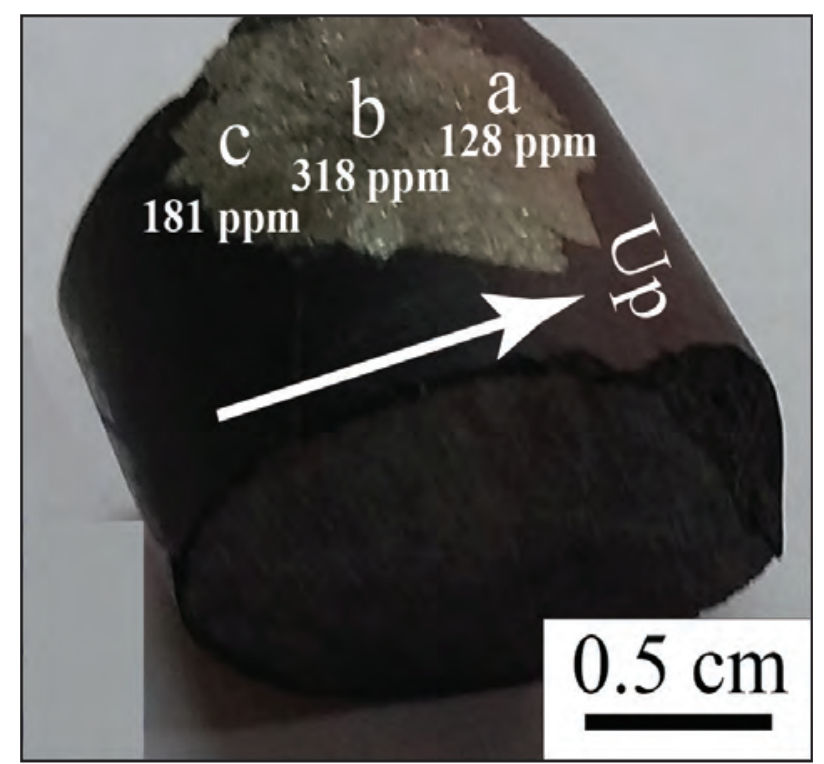

Figure 7. Centimetre-sized pyrite sample hosted in black shale of the Lockatong Fm, showing the analyzed spots; a and c: rims; b: core. $(\mathrm{a}=\mathrm{T} 2729.2 \mathrm{aPy}, \mathrm{b}=\mathrm{T} 2729.2 \mathrm{bPy}, \mathrm{c}=$ T2729.2cPy, refer to Table 3 for more details) 


\section{Quantity and maturity of organic matter}

The TOC values vary between 0.6 and $2.72 \%$ and between 0.8 and $1.9 \%$, respectively, in the Nursery and Titusville cores (Table 4). These values indicate that the black shales are relatively rich in organic matter and are considered as fair to good source rocks for hydrocarbons (petroleum and gas).

The hydrogen index (HI) of the analyzed samples is less than $100 \mathrm{mg} \mathrm{HC} / \mathrm{g}$ TOC, indicating that the organic matter in the analyzed samples seems to be is kerogen of type III. The HI values were not originally low, but rather reveal loss in hydrogen content due to organic matter maturity. The $\mathrm{T}_{\max }$ values are widespread $\left(304-608^{\circ} \mathrm{C}\right)$ and are unreliable due to the very low $\mathrm{S}_{2}$ values. Using the equation $\mathrm{T}_{\max }=\left(\mathrm{R}_{0}+7.16\right) /$ 0.018 (Peters et al. 2005) and the available $\mathrm{R}_{0}$ data (1.94 to $2.69 \%$ (Malinconico 2010), the calculated $\mathrm{T}_{\max }$ range from 506 to $531^{\circ} \mathrm{C}$ (Table 4). These $\mathrm{T}_{\max }$ values indicate that organic matter of the analyzed samples is over mature and had already generated hydrocarbons (oil and gas). In fact, the presence of bitumen in the cores (Fig. 8) indicates that the organic matter in these rocks had already generated hydrocarbons.

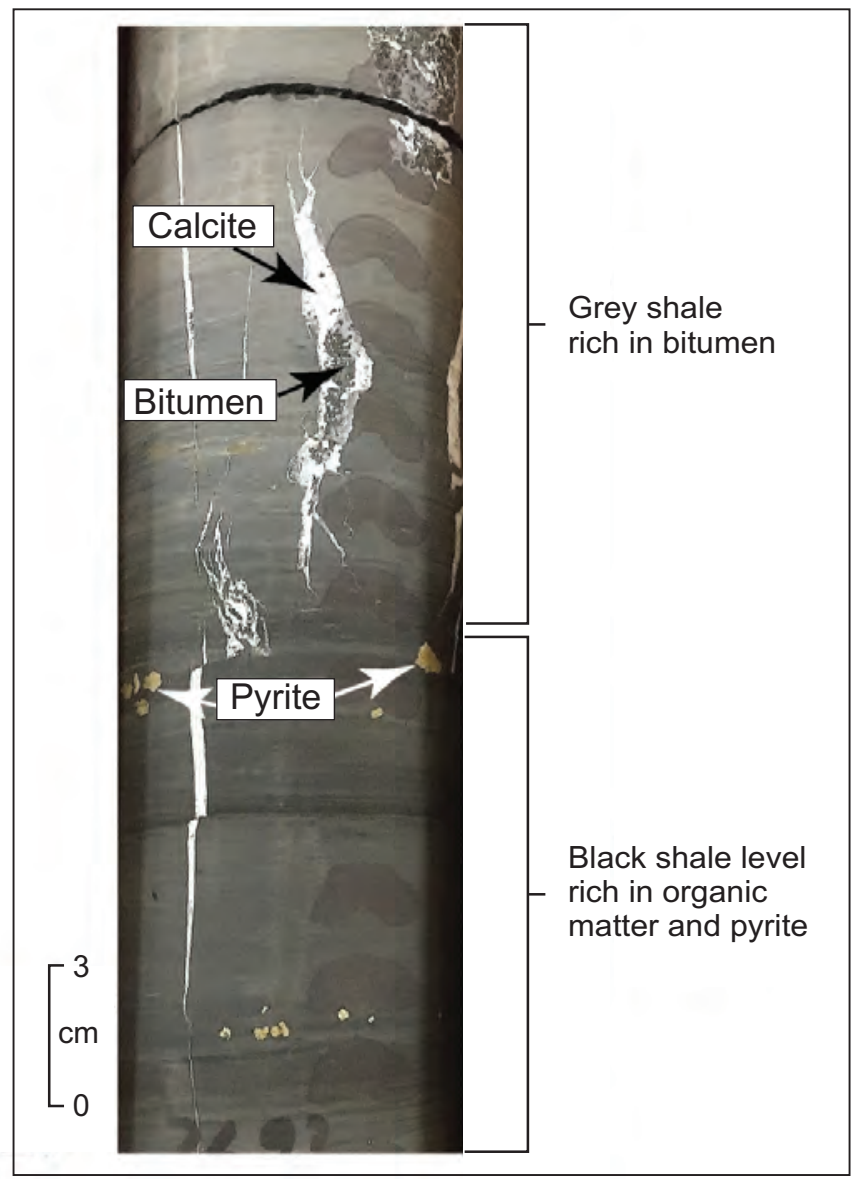

Figure 8. Alternating black shale rich in pyrite and grey shale rich in bitumen.
Arsenic in black shale and bitumen

The arsenic values for black shale samples from the Nursery core range from 15.4 to $33.6 \mathrm{mg} / \mathrm{kg}$ (mean $=21.9$ $\mathrm{mg} / \mathrm{kg})$ with one value $(1.4 \mathrm{mg} / \mathrm{kg})$ recorded in a light grey sample (Table 5). The arsenic values vary between 17.1 and $22.9 \mathrm{mg} / \mathrm{kg}$ (mean $=20.3 \mathrm{mg} / \mathrm{kg}$ ) for black shale samples from the Titusville core (Table 5). These values generally fall within the range of those determined by Serfes et al. (2010) $(10-110 \mathrm{mg} / \mathrm{kg}$; mean $=60 \mathrm{mg} / \mathrm{kg})$ for the Newark basin, and by Blake and Peters (2015) (10-35 mg/kg; mean $=23 \mathrm{mg} / \mathrm{kg}$ ) for the Newark and Gettysburg basins. Other analyzed TE, in particular Mo, Cr, Th, and $\mathrm{U}$, show high concentrations reaching a maximum of $230,90,15.9,14.6$ $\mathrm{mg} / \mathrm{kg}$, respectively. Ni shows concentrations below detection limit $(<20 \mathrm{mg} / \mathrm{kg})$. Some of these elements (Mo, Cr, U, As) are redox-sensitive trace elements that indicate anoxic to euxinic conditions under which organic matter is deposited (Tribovillard et al. 2006).

It is known that arsenic and other TE are commonly absorbed onto organic matter through bio-concentration of elements by organisms during sedimentation (Arthur et al. 1988) and the chelation of elements during early diagenesis (Disnar 1982, 1996; Trichet at al. 1987). Through the plots of As versus organic matter phases/contents (TOC, PC, $\mathrm{RC}$ ), it is possible to find out the organic matter phase to which As is mainly linked. Due to the over-maturity of the $\mathrm{OM}, \mathrm{PC}$ is tremendously reduced ( $\mathrm{PC}=0.01-0.02 \mathrm{wt} \%$ ). Therefore, correlation between As and PC is not possible. Given that $\mathrm{TOC} \approx \mathrm{RC}$, only correlation between TOC and As is attempted. A plot of As versus TOC in the black shale samples reveals weak correlation between organic matter and trace elements, including As (Fig. 9). This suggests a priori the absence of geochemical affinity between $\mathrm{OM}$ and As. Two explanations are proposed to account for the absence of the OM-As affinity. First, the arsenic is likely partitioned into $\mathrm{OM}$, diagenetic pyrite, and oxyhydroxide phases (Fig. 10a). The competition of these three phases (OM, pyrite, oxyhydroxide) in sequestering arsenic resulted in the lack of positive correlation between As and OM. Second, the over- maturity of organic matter altered the expected positive covariance between As and TOC (Fig. 9).

Diagenetic processes are known to induce the transfer of some arsenic from organic matter to pyrites (Tribovillard et al. 2006). This arsenic expulsion from organic matter and its incorporation into pyrite led to the further enrichment of pyrite relative to black shales (Fig. 10b).

During early diagenesis, the decomposition of organic matter resulted in the release of arsenic from organic matter and its incorporation in pyrite. Due to the intense maturity of the OM, it is likely that most of the arsenic was transferred from organic matter to pyrite during catagenetic processes. The latter took place during active subsidence where organic matter of the Lockatong Formation including the Walls Island and Byram members in both the Titusville 

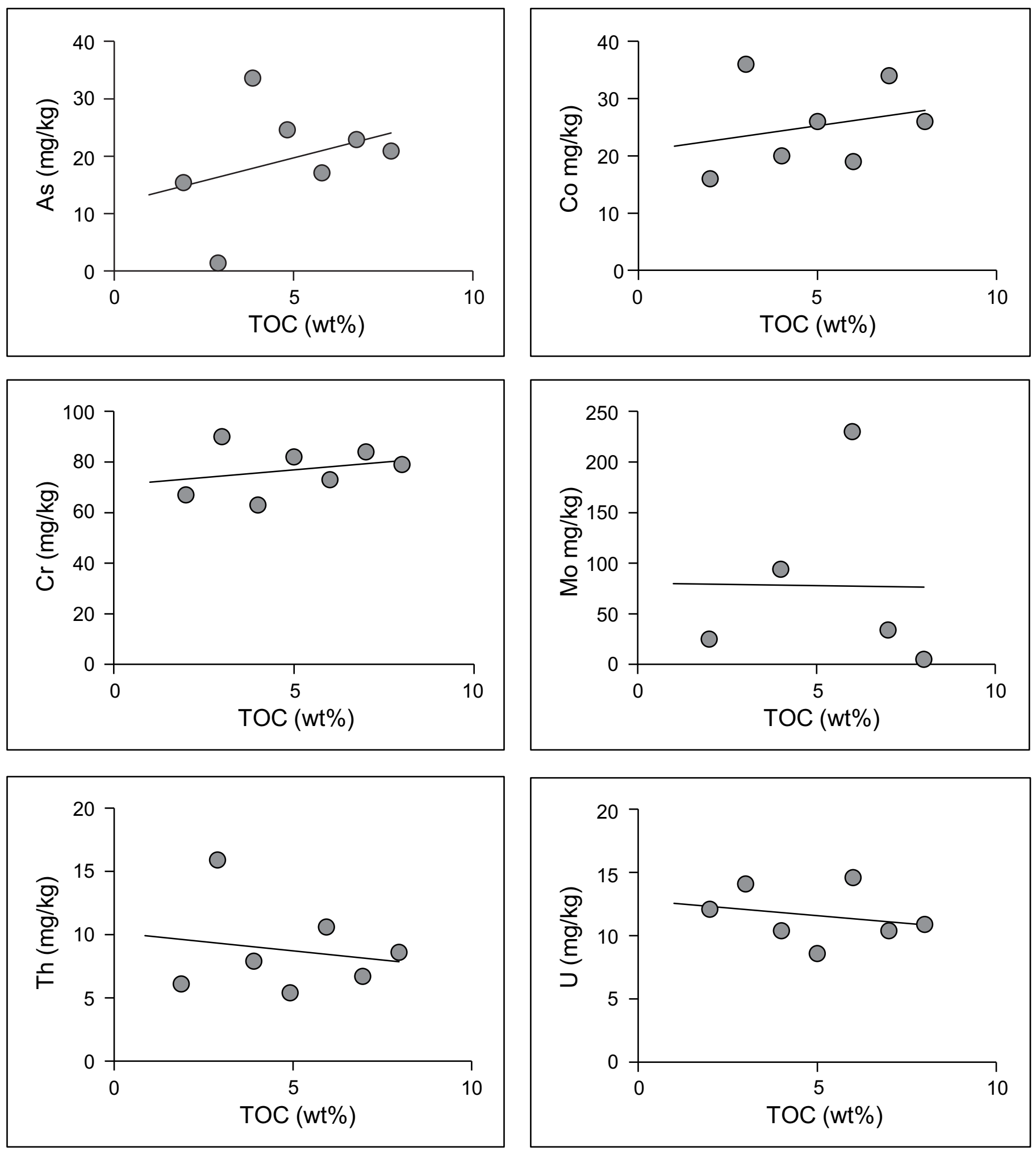

Figure 9. Plots between trace elements and TOC in black shale samples of the Nursery and Titusville cores, Lockatong Formation. 


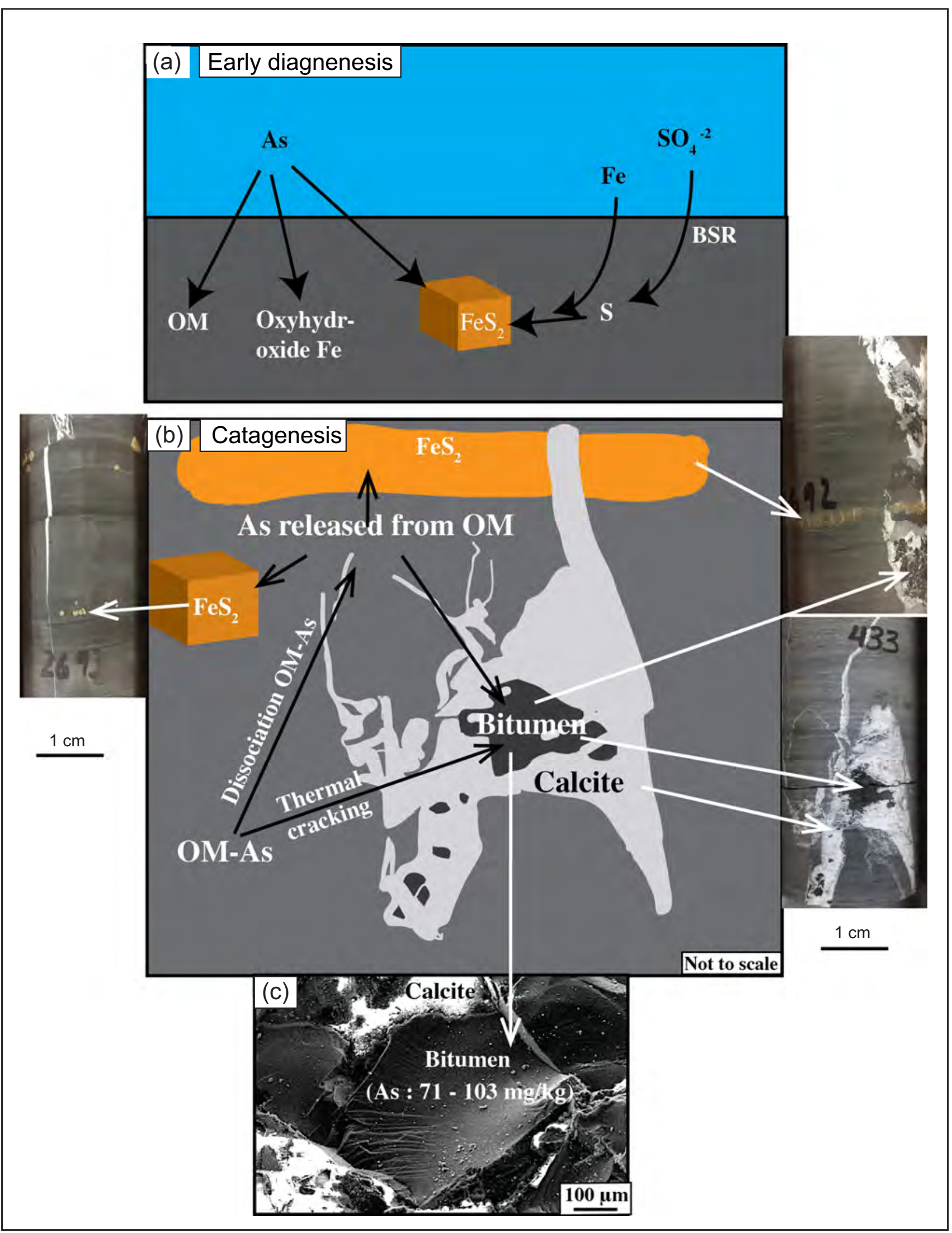

Figure 10. Distribution of arsenic during (a) early diagenesis and (b) late diagenesis processes (Catagenesis), and (c) concentration of As in bitumen in the Lockatong Formation. As: Arsenic, Fe: Iron, S: Sulfur, $\mathrm{SO}_{4}^{-2}$ : Dissolved sulfate ions, $\mathrm{FeS}_{2}$ : Pyrite, OM: Organic matter, OM-As: Organic matter-As complexes, BSR: Bacterial sulfate reduction. 
and Nursery cores underwent catagenetic transformation. This catagenesis reduced the amount of the original TOC initially preserved in the black shale. Consequently, a fraction of the metal endowment, initially concentrated in organic matter during sedimentation and early diagenesis, was released and migrated along with the hydrocarbons (bitumen) (Fig. 10c). Dissociation of the organo-elements complexes resulted in the lack of a positive correlation between these elements and organic matter. A fraction of the expelled elements was subsequently incorporated into pyrite whereas the other fraction was partitioned into the bitumen phase, which contains high arsenic concentration (71-103 $\mathrm{mg} / \mathrm{kg}$ ) (Table 5). The overpressure caused by the accumulation and saturation of hydrocarbons within the pores may have cracked the rocks (hydraulic fracturing) liberating the arsenic, other TE, and hydrocarbons. The Asrich bitumen migrated from the adjacent organic matterrich black shale and subsequently filled the available fractures typically hosted in grey shale (Fig. 8). The As-rich bitumen fractures can be considered as a potential source of arsenic in groundwater.

\section{Model for arsenic fixation and redistribution during diagenetic processes}

The proposed model for the fixation and redistribution of arsenic is illustrated in Figure 10. The development of euxinic/anoxic conditions was crucial in the fixation of arsenic and other trace elements in pyrite and organic matter. These conditions enhanced the preservation of organic matter, the production of sulfur via BSR, and ultimately the formation of pyrite in the presence of reactive iron (Fig. 10). These reducing conditions promoted the incorporation of arsenic and other trace elements in organic matter during sedimentation and early diagenesis. These elements were also incorporated in the diagenetic pyrite. The latter has been considered as a potential sink for arsenic in organic matter-rich shale in the Newark basin (Serfes et al. 2005; Blake and Peters 2015; Rddad 2016) and in other locations worldwide (Huerta-Diaz and Morse 1992; Tribovillard et al. 2006). During the catagenetic transformation of OM, a fraction of arsenic and other trace elements would have been expelled from OM-rich black shale and incorporated in pyrite and bitumen (Fig. 10). The latter migrated and filled small fractures in the adjacent grey shale (Fig. 8).

This model clearly shows that the organic matter richness, dependent on anoxic conditions during sedimentation and early diagenesis, and the degree of organic matter maturity, dependent on later diagenetic/ catagenetic processes, are the important controls on the amount of As in black shale and groundwater. The anoxic events developed in the Newark basin correspond to OM- and pyrite-rich black shale facies of the Lockatong Formation. These facies extend laterally over large distances. Given the fact that the Lockatong Formation is over-mature, the anoxic, dark layers with high TOC values and the associated abundant bitumen rich-veins help to predict the regions of high arsenic concentration in groundwater. The remobilization of arsenic from pyritic black shale is achieved through the oxidation of pyrite releasing arsenic which is subsequently adsorbed onto hydrous ferrous oxide (Serfes et al. 2010). While Arsenic can be derived from the oxidation of pyrite, it can be also sourced from bitumen-rich fractures. In fact, given the fact that the black shale in the Lockatong Formation has very low permeability, the groundwater flows mainly through available interconnected small fractures commonly filled with arsenic-rich bitumen. It follows that these bitumen-rich fractures can be also potential source of arsenic contaminating the groundwater in the Newark basin. Moreover, the interconnected small fractures offered suitable contact surfaces between flowing groundwater and As-rich pyritic black shale. The groundwater flowing through these veins removes arsenic from As-rich pyritic black shale causing As contamination of the groundwater.

\section{CONCLUSIONS}

Based on the geochemical data presented in this paper, the following conclusions can be drawn.

1. Euxinic/anoxic conditions enhanced the preservation of OM, the generation of sulfide via BSR during early diagenesis, and subsequent formation of diagenetic pyrite. The latter is a potential sink for arsenic and other trace elements as has been proposed previously by Serfes et al. (2005). The development of these euxinic/anoxic conditions controls the original concentration of As in the pyritic black shale.

2. The thermal cracking of organic matter has caused the dissociation of the organo/inorganometallic complexes resulting in the release of arsenic and other TE. These elements were subsequently incorporated into pyrite and bitumen.

3. The bitumen-rich veins are enriched in arsenic, and are considered as source of As in groundwater.

4. Considering the low permeability of the Lockatong Formation, the groundwater is forced to flow through the numerous interconnected veins and consequently leaches arsenic from black shale and oxidizes available pyrite minerals. This further contributes to the arsenic contamination of the groundwater.

\section{ACKNOWLEDGEMENTS}

The author would like to thank Dr. P. Olsen of Columbia University and Drs. D. Kent and J. Browning of Rutgers University for providing the samples for this project. I also thank Alan Koenig of the USGS, Denver, for analyzing pyrite samples with LA-ICP-MS. I am also grateful to two anonymous journal reviewers whose comments and suggestions greatly improved the quality of the paper. 
I am also grateful to Dr. MaryAnn Malinconico of the Lafayette College, PA for the fruitful comments on organic matter section. I also thank journal co-editor Dr. Chantel Nixon for handling the reviewing process, and co-editor Dr. Sandra Barr for handling and copy-editing the paper. I am also grateful to Kingsborough's Associate Provost Dr. Reza Fakhari for his ongoing support. I also thank Robert Schenk, Scanning Electron Microscope operator at the Physical Science Department of Kingsborough Community College, for assisting me locate the bitumen for trace element analysis. This project has also benefited from a Geological Society of America grant for one of my undergraduate students and from CUNY Research Scholars Program (CRSP) that supported one of my scholar students.

\section{REFERENCES}

Arthur, M.A., Jenkyns, H.C., Brumsack, H.J., and Schlanger, S.O. 1988. Stratigraphy, geochemistry, and paleoceanography of organic carbon-rich Cretaceous sequences. In Cretaceous Resources, Events and Rhythms: Background and Plans for Research. Edited by R.N. Ginsburg and B. Beaudoin. Kluwer Academic Publishers, Digne, France, pp. 75-119.

Ayotte, J.D., Montgomery, D.L., Flanagan, S.F., and Robinson, K.W. 2003. Arsenic in groundwater in eastern New England: occurrence, controls, and human health implications. Environmental Science and Technology, 37, pp. 2075-2083. https://doi. org/10.1021/es026211g

Bajwah, Z.U., Seccombe, P.K., and Offler, R. 1987. Trace element distribution, $\mathrm{Co}: \mathrm{Ni}$ ratios and genesis of the Big Cadia iron-copper deposit, New South Wales, Australia. Mineralium Deposita, 22, pp. 292-300. https://doi.org/10.1007/BF00204522

Berner, R.A. 1984. Sedimentary pyrite formation: An update: Geochimica et Cosmochimica Acta, 48, pp. 605-615. https://doi.org/10.1016/00167037(84)90089-9

Blake, J.M. and Peters, S.C. 2015. The occurrence and dominant controls on arsenic in the Newark and Gettysburg basins. Science of the Total Environment, 505, pp. 1340-1349. https://doi.org/10.1016/j. scitotenv.2014.02.013

Claypool, G.E., Holseer, W.H., Kaplan, I.R., Sakai, H., and Zak, I. 1980. The age curve of sulphur and oxygen isotopes in marine sulphate and their mutual interpretation. Chemical Geology, 28, pp. 163-187. https://doi.org/10.1016/0009-2541(80)90047-9

Deditius, A.P., Utsunomiya, S., Renock, D., Ewing, R.C., Ramana, C.V., Becker, U., and Kesler, S.E. 2008. A proposed new type of arsenian pyrite: Composition, nanostructure and geological significance. Geochimica et Cosmochimica Acta, 72, pp. 2919-2933. https://doi. org/10.1016/j.gca.2008.03.014
Dill, H. and Kemper, E. 1990. Crystallographic and chemical variations during pyritization in the upper Barremian and lower Aptian dark claystones from the Lower Saxonian Basin (NW Germany): Sedimentology, 37, pp. 427-443. https://doi.org/10.1111/j.1365-3091.1990. tb00145.x

Disnar, J.R. 1982. Etude expérimentale de la fixation de divers métaux sur une matière organique sédimentaire dorigine algaire. Maturation thermique des composés formés. Thèse de doctorat Es-Sci, Université Orléans, France, $283 \mathrm{p}$.

Disnar, J.R. 1996. A comparison of mineralization histories for two MVT deposits, Trèves and Les Malines (Causses basin, France), based on the geochemistry of associated organic matter. Ore Geology Reviews, 11, pp. 133-156. https://doi.org/10.1016/0169-1368(95)00019-4

El Tabakh, M. and Schreiber, B. C. 1998. Diagenesis of the Newark basin Rift basin, eastern North America. Sedimentology, 45, pp. 855-874. https://doi. org/10.1046/j.1365-3091.1998.00183.x

El Tabakh, M., Rita, R., and Schreiber, B.C. 1997. Evolution of late Triassic rift basin evaporites (Passaic Formation): Newark Basin, Eastern North America. Sedimentology, 44, pp. 767-790. https://doi. org/10.1046/j.1365-3091.1997.d01-47.x

Espitalié, J., Deroo, G., and Marquis, F. 1985. La pyrolyse Rock-Eval et ses applications. 2ème partie. Revue de l'Institut Francais du Petrole, 40, pp. 755-784.

Gautier, D. L. 1986. Isotopic composition of pyrite: relationship to organic matter type and iron availability in some North American Cretaceous shales. Chemical Geology, 65, pp. 293-303.

Giesemann, A., Jager, H.J., Norman, A.L., Krouse, H.P., and Brand, W.A. 1994. On-line sulfur isotope determination using an elemental analyzer coupled to a mass spectrometer. Analytical Chemistry, 66, pp. 2816-2819. https://doi.org/10.1021/ac00090a005

Gomes, M.L. and Hurtgen M.T. 2015. Sulfur isotope fractionation in modern euxinic systems: Implications for paleoenvironmental reconstructions of paired sulfate-sulfide isotope records. Geochimica et Cosmochimica Acta, 157, pp. 39-55. https://doi. org/10.1016/j.gca.2015.02.031

Gomes, M.L. and Hurtgen, M.T. 2013. Sulfur isotope systematics of a euxinic, low-sulfate lake: Evaluating the importance of the reservoir effect in modern and ancient oceans. Geology, 41, 6, pp. 663-666. https:// doi.org/10.1130/G34187.1

Grassineau, N.V., Mattey, D.P., and Lowry, D. 2001. Sulfur isotope analysis of sulfide and sulfate minerals by continuous flow-isotope ratio mass spectrometry. Analytical Chemistry, 73, pp. 220-225. https://doi. org/10.1021/ac000550f

Guy, B.M., Beukes, N.J., and Gutzmer, J. 2010. Paleoenvironmental controls on the texture 
and chemical composition of pyrite from nonconglomeratic sedimentary rocks of the Mesoarchean Witwatersrand Supergroup, South Africa. South African Journal of Geology, 113, pp. 195-228. https:// doi.org/10.2113/gssajg.113.2.195

Huerta-Diaz, M.G. and Morse, J.W. 1992. Pyritization of trace metals in anoxic marine sediments. Geochimica et Cosmochimica Acta, 56, pp. 2681-2702. https:// doi.org/10.1016/0016-7037(92)90353-K

Jones, B. and Manning, D.A. C. 1994. Comparison of Geochemical Indexes Used for the Interpretation of Palaeoredox Conditions in Ancient Mudstones. Chemical Geology, 111, pp. 111-129. https://doi. org/10.1016/0009-2541(94)90085-X

Jørgensen, B.B. 1979. A theoretical model of the stable sulfur isotope distribution in marine sediments. Geochimica et Cosmochimica Acta, 43, pp. 363-374.

https://doi.org/10.1016/0016-7037(79)90201-1

Lipfert, G., Reeve, A.C., Sidle, W.C., and Marvinney, R. 2006. Geochemical patterns of arsenic-enriched groundwater in fractured, crystalline bedrock, Northport, Maine, USA. Applied Geochemistry, 21, pp. 528-45. https://doi.org/10.1016/j. apgeochem.2005.12.001

Loftus-Hills, G. and Solomon, M. 1967. Cobalt, nickel and selenium in sulfides as indicators of ore genesis. Mineralium Deposita, 2, pp. 228-242. https://doi. org/10.1007/BF00201918

Longerich, H.P., Jackson, S.E., and Günther, D. 1996. Laser Ablation Inductively Coupled Plasma Mass Spectrometric Transient Signal Data Acqusition and Analyte Concentration Calculation. Journal of Analytical Atomic Spectrometry, 11, pp. 899-904. https://doi.org/10.1039/JA9961100899

Lyons, T. W. 1997. Sulfur isotopic trends and pathways of iron sulfide formation in upper Holocene sediments of the anoxic Black Sea. Geochimica et Cosmochimica Acta, 61, pp. 3367-3382. https://doi.org/10.1016/ S0016-7037(97)00174-9

Machel, H. G. 2001. Bacterial and thermochemical sulfate reduction in diagenetic settings - old and new insights. Sedimentary Geology, 140, pp. 143-175. https://doi.org/10.1016/S0037-0738(00)00176-7

Malinconico, M.L. 2010. Synrift to early postrift basinscale groundwater history of the Newark basin based on surface and borehole vitrinite reflectance data. In Contributions to the Geology and Hydrogeology of the Newark Basin. Edited by G.C. Herman and M.E. Serfes. New Jersey Geological Survey Bulletin 77, Chapter C., pp.1-38.

Manspeizer, W. 1988. Triassic-Jurassic rifting and opening of the Atlantic: An overview. In Triassic- Jurassic rifting, continental breakup, and the formation of the Atlantic Ocean and passive margins, Part A. Edited by W. Manspeizer. Amsterdam, Netherlands, Elsevier, pp. 41-79. https://doi.org/10.1016/B978-0-44442903-2.50008-7
Nance, R.D. and Linneman, U. 2008. The Rheic Ocean: Origin, evolution, and significance. GSA Today, 18, pp. 4-12. https://doi.org/10.1130/GSATG24A.1

Olsen, P.E. 1980. Triassic and Jurassic formations of the Newark basin. In Field Studies in New Jersey Geology and Guide to Field Trips. Edited by W. Manspeizer. 52nd Annual Meeting, New York State Geological Association, Newark College of Arts and Sciences, Newark, Rutgers University, pp. 2-39.

Olsen, P.E. 1986. Milankovitch cycles in Early Mesozoic rift basins of Eastern North America provide physical stratigraphy and time scale for understanding basin evolution: Lamont (Newsletter), 13, pp. 5-6.

Olsen, P.E., Kent, D.V., Cornet, B., Witte, W.K., and Schlische, R.W. 1996. High-resolution stratigraphy of the more than $5000 \mathrm{~m}$ Newark rift section (early Mesozoic, eastern North America): Geological Society of America Bulletin, 108, pp. 40-77. https:// doi.org/10.1130/0016-7606(1996)108<0040:HRSOT $\mathrm{N}>2.3 . \mathrm{CO} ; 2$

O'Shea, B., Stransky, M., Leitheiser, S, Brock, P., Marvinney, R.G., and Zheng, Y. 2015. Heterogeneous arsenic enrichment in meta-sedimentary rocks in central Maine, United States. Science of the Total Environment, 505, pp.1308-1319. https://doi. org/10.1016/j.scitotenv.2014.05.032

Pattan, J.N. and Pearce, N.J.G. 2009. Bottom water oxygenation history in southeastern Arabian Sea during the past $140 \mathrm{ka}$ : results from redox-sensitive elements. Palaeogeography, Palaeoclimatology, Palaeoecology, 280, pp. 396-405. https://doi. org/10.1016/j.palaeo.2009.06.027

Peters, K.E., Walters, C.C., and Moldowan, J.M. 2005. The biomarker guide, second edition, volume I, biomarkers and isotopes in petroleum systems and human history. United Kingdom, Cambridge University Press, $476 \mathrm{p}$.

Peters, S.C. 2008. Arsenic in groundwaters in the Northern Appalachian Mountain belt: a review of patterns and processes. Journal of Contaminant Hydrology, 99, pp. 8-21. https://doi.org/10.1016/j.jconhyd.2008.04.001

Peters, S.C. and Burkert, L. 2007. The occurrence and geochemistry of arsenic in groundwaters of the Newark Basin of Pennsylvania. Applied Geochemistry, 23, pp. 85-98. https://doi.org/10.1016/j. apgeochem.2007.10.008

Ratcliffe, N.M., Burton, W.C., D'Angelo, R.M., and Costain, J.K. 1986. Low-angle extensional faulting, reactivated mylonites, and seismic reflection geometry of the Newark basin margin in eastern Pennsylvania. Geology, 14, pp. 766-770. https://doi. org/10.1130/0091-7613(1986)14<766:LEFRMA>2.0. $\mathrm{CO} ; 2$

Rddad, L. 2016. Role of euxinic conditions in adsorbing Arsenic and Trace elements in organic matter and pyrites preserved in the Lockatong Formation of the Newark basin: Implication to the quality of 
groundwater. Northeastern Section Geological Society of America, Albany New York. Geological Society of America Abstracts with Programs, 48, no. 2.

Ryan, P. C, Kim, J., Mango, H., Hattori, K., and Thompson A. 2013. Arsenic in a fractured slate aquifer system, New England (USA): influence of bedrock geochemistry, groundwater flow paths, redox and ion exchange. Applied Geochemistry, 39, pp. 181-192. https://doi.org/10.1016/j.apgeochem.2013.09.010

Ryan, P.C., West, D.P., Hattori, K., Studwell, S., Allen, D.N., and Kim, J. 2015. The influence of metamorphic grade on arsenic in metasedimentary bedrock aquifers: a case study from western New England, USA. Science of the Total Environment, 505, pp. 1320-1330. https:// doi.org/10.1016/j.scitotenv.2014.05.021

Sælen, G. Raiswell, R., Talbot, M.R., Skei J.M., and Bottrell S.H. 1993. Heavy sedimentary sulfur isotopes as indicators of super-anoxic bottom-water conditions. Geology, 21, pp. 1091-1094. https://doi. org/10.1130/0091-7613(1993)021<1091:HSSIAI>2.3. $\mathrm{CO} ; 2$

Schlische, R.W. and Olsen, P.E. 1990. Quantitative filling models for continental extensional basins with application to the early Mesozoic rifts of eastern North America. Geology, 98, pp. 135-155. https://doi. org/10.1086/629390

Schlische, R.W., Withjack, M.O., and Olsen, P.E. 2003. Relative timing of CAMP, rifting, continental breakup, and basin inversion: Tectonic significance. In The Central Atlantic Magmatic Province, Insights from fragments of Pangea. Edited by W.E. Hames, J.G. McHone, P.R. Renne, and C. Ruppel. American Geophysical Union, Geophysical Monograph 136, pp. 33-59. https://doi.org/10.1029/136GM03

Serfes, M., Herman, G., Spayd, S., and Reinfelder, J. 2010. Sources, mobilization and transport of arsenic in groundwater in the Passaic and Lockatong Formations of the Newark basin, New Jersey. New Jerset Geological Society Bulletin, 77, pp. 1-40.

Serfes, M.E., Spayd., S.E., Herman, G.C. 2005. The occurrence, sources, mobilization, and transport of Arsenic in groundwater in the Newark basin of New Jersey. In Advances in Arsenic Research; Integration of experimental and observational studies and implications for mitigation, Symposium Series 915. Edited by P.A. O'Day, Vlassopoulos, Meng, Xiaoguang, and L.G. Benning. American Chemical Society, Washington, D.C., pp. 175-190.

Smedley, P.L. and Kinniburgh D.G. 2002. A review of the source, behavior and distribution of arsenic in natural waters. Applied Geochemistry, 17, pp. 517-68. https:// doi.org/10.1016/S0883-2927(02)00018-5

Tissot, B.P. and Welte, D.H. 1978. Petroleum Formation and Occurrences, Springer-Verlag, New York, 538 p. https://doi.org/10.1007/978-3-642-96446-6

Tribovillard, N., Algeo, T.J., Lyons, T., and Riboulleau, A. 2006. Trace metals as paleoredox and paleoproductivity proxies: An update. Chemical Geology, 232, pp. 12-32. https://doi.org/10.1016/j.chemgeo.2006.02.012

Tribovillard, N., Ramdani, A., and Trentesaux, A. 2005. Controls on organic accumulation in Late Jurassic shales of northwestern Europe as inferred from tracemetal geochemistry. In The Deposition of OrganicCarbon-Rich Sediments: Models, Mechanisms, and Consequences. Edited by N. Harris. SEPM Special Publication, 82, pp. 145-164. https://doi.org/10.2110/ pec.05.82.0145

Trichet, J., Disnar, J.R., Bonnamy, S., Gauthier, B., Nakashima, S., Oberlin, A., Perruchot, A., and Rouz, J.N. 1987. Le comportement mutual de la matière organique et des métaux: Implications géochemiques et métallogeniques. Mémoires de la Societe Géologique de France, 51, pp. 143-162.

Van Houten, F.B. 1964. Cyclic lacustrine sedimentation, Upper Triassic Lockatong Formation, New Jersey and adjacent Pennsylvania. In Symposium on Cyclic Sedimentation. Edited by D.F. Merriam. Kansas Geological Survey Bulletin, 169, pp. 497-531.

Wilson, S.A., Ridley, W.I., and Koenig, A.E. 2002. Development of sulfide calibration standards for the laser ablation inductively coupled plasma mass spectrometry technique. Journal of Analitical Atomic Spectromery, 17, pp. 406-409. https://doi.org/10.1039/ $\mathrm{B} 108787 \mathrm{H}$

Editorial responsibility: Chantel Nixon and Sandra M. Barr 